\title{
Public Procurement In Infrastructure Projects In Dr Congo: Legal Control Of Relevant Ministries
}

\author{
Bienvenu Mbom Kitoko
}

\section{INTRODUCTION}

In the Democratic Republic of Congo, public procurement is currently governed mainly ${ }^{1}$ by Law No. 10/10 of 27 April 2010 on public Procurement ${ }^{2}$. This text of 85 articles in seven (7) headings provides rules and procedures for the preparation, execution, execution, management and control of contracts for public procurement purposes and for the purpose of reflecting transparency, credibility and the profitability of the state action. The above-mentioned law at the same time lays down the rules on public service delegations, the contracts awarded by private legal entities with private law but benefiting from the financing or guarantee of legal persons of public law or acting on their behalf and for his account.

In addition, the Congolese constitution of 18 February 2006 as amended by Law No. 11/002 of 20 January 2011 revising certain articles of the Constitution of the Democratic Republic of Congo, in its explanatory memorandum, makes good governance and the fight against the impunity of high-end values. In this respect, the Decree on the Manual of Procedures of the Law on Public Procurement, in its article 8, insists on the freedom of access to public procurement, the equality of candidates, transparency and efficiency of procedures as well as budgeting of public procurement.

It should be noted that Article 7 of the Public Procurement Act provides for four types of public procurement: works contracts, supply contracts, service contracts and intellectual services contracts.

To comply with this topic, our particular attention is focused on works contracts. In fact, according to Article 8 of the aforementioned law, these "have for their object the realization for the benefit of a contracting authority of all works building or civil engineering or the repair of works of any kind. "It is therefore to this type of public market that the infrastructure projects are basically oriented.

1 There are also other regulatory texts such as: Decree No. 10/21 of 2 June 2010 on the creation, organization and functioning of the Public Procurement Regulatory Authority; Decree No. 10/27 of 28 June 2010 on the establishment, organization and functioning of the General Directorate for the Control of Public Procurement; Decree No. 10/32 of 28 December 2010 establishing, organizing and operating the Project Management and Public Procurement Unit; Decree No. 10/22 of 2 June 2010 on the Procedural Manual of the Law on Public Procurement; Decree No 10/34 of 28 December 2010 laying down the procedures for the approval of public contracts and public service delegations; Decree No 10/34 of 28 December 2010 setting the thresholds for the award, control and approval of public contracts; Decree No. 039/2001 of 08 August 2001 establishing, organizing and operating the Central Coordination Office.

2 In Official Journal of the Democratic Republic of the Congo, special issue of April 30, 2010. 
In fact, infrastructure projects have the advantage of significantly reducing poverty, contributing to the socio-economic recovery of the country and allowing access to markets and social and administrative services, especially for the African States. They are in the process of continuous development. Public procurement represent a very considerable part of the budget of each country and ensure the use of taxpayers' money and the effectiveness of public policies.

Particularly in the case of DR Congo, infrastructure projects can only be welcomed, particularly in view of its strategic location in central Africa, its dynamic demography and its innumerable natural resources, the importance of which can be more clearly demonstrated... It is for all these reasons that infrastructure is currently one of the priorities of the DRC Government as part of its plan for the Revolution of Modernity.

In general, the competent authority shall decide on the file forwarded to it by the contracting authority. This file includes, in addition to the form indicating the nature and number of documents constituting the approval file, the presentation report specifying the subject of the contract or the amendment, the tax or customs regime of the contract or amendment, the favorable opinion of the DGCMP (Public Procurement control general direction), the contract or addendum signed by the contracting parties and the document justifying the existence of budget availability or procurement financing.

It is mandatory to attach to the approval file, the minutes drawn up by the Procurement Committee attesting the award of the contract or the certified copy issued by the President of the Public Procurement Management Unit concerned, for the public service contracts or delegations awarded by the tendering procedure and the authorization of the DGCMP, for those passed through the restricted or OTC tender procedure ${ }^{3}$.

The approval of the contract or the delegation of public services is effective only after the affixing of the visa on the file while the beginning of the execution or the public service delegation is subordinated to the affixing of the signature of the approving authority in the box therein.

Finally, the approval decision is notified within three days of the date of signature of the contract or approval by the competent authority. It may take place on another date, if the procurement so provides. It is in reality this notification that marks the entry into force of the contract or the public service delegation.

Within fifteen (15) days after the entry into force of the contract or the public service delegation, a final award notice shall be published in the public procurement journal or any other accredited newspaper ${ }^{4}$.

3 Article 9 of Decree No 10/33 of 22 December 2010 laying down the procedures for the approval of public contracts and public service delegations.

4 Article 12 of Decree No 10/33 of 22 December 2010 referred to above. 
In case of refusal, the competent authority shall notify its duly reasoned written decision within ten days of transmission of the approval file. The Contracting Party concerned may challenge this decision before ARMP (Public procurement regulating Autority) ${ }^{5}$.

As can be seen, the development of the awarding of public procurement can only be achieved through effective, efficient and effective control of the ministries concerned, whose analysis is now required. This control is of several orders. It is technical, administrative, financial, political, jurisdictional, etc. But in the context of this reflection, we are examining it mainly from the legal point of view. Thus, there is plurality of institutions (1) and the implementation of their legal control (2).

\section{Different authorities of control}

The legal control of public procurement in DR Congo is effectively ensured by administrative, financial and jurisdictional bodies.

At the administrative level, the control of the execution of the public works contract is mainly ensured by the authority to implement it and / or to sign it: it is the competent authority ${ }^{6}$ or the contracting authority ${ }^{7}$. But because of the technical nature of certain public procurements $^{8}$, it is accepted that the execution is entrusted to a third person: the executive officer or the supervisor? 9

But the legislator has provided an administrative device capable of ensuring the proper execution of public contracts. Some are responsible for the management and approval of public procurement contracts while others are responsible for the control. They are the contracting authority, the Public Procurement Control Directorate, the Public procurement Regulatory Authority. public authorities and approving authorities ${ }^{10}$.

Financial control is exercised by the Court of Auditors and the Inspectorate General of Finance.

5 Art. 13 of the same decree.

6 By Contracting Authority is meant, according to the terms of Article 5 of the Congolese law on public procurement: any legal person under public law or legal person private law or his delegate, responsible for defining public projects sector under its responsibility, to prepare and plan for implementation under the public procurement procedure, to monitor and monitor.

7 Hear here the contracting authority on whose behalf the execution of the works or the supply of equipment is carried out.

8 Thus, the client provides mandatory assistance at the time of placing and receiving the work. To this end, he personally directs the execution of works, the steering, scheduling and coordination of the site. This is the role that the Congolese Agency for major works plays in the DRC.

9 According to Article 5, it is any natural or legal person governed by public law or private law entrusted by the contracting authority with the representation and defense of its interests at the stages of the definition, elaboration, execution and receipt of services, subject of the contract.

10 It concerns the Prime Minister or the Minister having the Budget in his attributions, but also, for the Provinces and the territorial entities decentralized, the authorities fixed by the provincial edicts organizing the awarding of the public contracts of their jurisdiction. 
The Court of Accounts is a technical body of the parliament charged with controlling the management of the state finances, the public goods as well as the accounts of the decentralized territorial entities and public bodies.

The General Inspectorate of Finance is a senior audit service of the government which ensures the control of finances and property, except those of the National Assembly. It verifies the correct use of public finances and the management of State property and carries out any investigation or mission of control, verification, counter-verification and supervision of the financial authorities of the State and all other services, organizations or institutions ordered, either on instruction of the President of the Republic, or on requisition of political and administrative authorities, or on the judicial authorities or on the denunciation of third parties $^{11}$. To this end, it contributes to the traceability and transparency of the public procurement, execution and management process.

From a legal point of view, the Congolese legislator has recognized the power of the judiciary to detect and censure acts that may be committed during the process of awarding and managing public contracts.

Thus, in addition to its traditional mission of seeking, in the field of law enforcement, infringements of legislative and regulatory acts committed in the territory of the Republic, in the field of public procurement, the prosecutor is responsible for prosecuting offenses related to public procurement and those that can be committed to commit to this effect. This is the case of insider trading, conflict of interest, illegal capture of interests, favoritism, misappropriation of public funds, corruption, forgery and misuse, as well as money laundering.

In addition, in order to perfect the control exercised by the public prosecutor's office, the judge, both administrative and judicial, inevitably intervenes for this purpose.

Indeed, in DR Congo, the judicial control of administrative acts is ensured by the Council of State, the Administrative Courts of Appeal and the administrative courts.

The Council of State decides, first and last resort, the remedies for violation of the Act formed against the acts, regulations and decisions of the central administrative authorities and, on appeal, the appeals against the decisions of the Administrative Courts of Appeal. The latter are competent to hear actions for annulment of the acts of the provincial and local authorities and the bodies under their supervision.

The State Council also knows, in the case where there are no other competent courts, claims for compensation for the compensation of exceptional damage, material or moral resulting from a measure taken by the authorities of the Republic. It is pronounced in equity, taking into account all circumstances of public or private interest ${ }^{12}$.

11 Art. 12 of Ordinance No. 87-323 of 15 September 1987 establishing the General Inspectorate of Finance.

12 Article 155 al. 1,2 and 3 of the DR Congo Constitution. 


\section{Implementation of public procurement control}

Currently in the Democratic Republic of Congo, only the Council of State is already operational. However, pending the actual establishment of the administrative courts referred to above, the administrative divisions of the Courts of Appeal shall act as such. In any case, they may only be seized of an application for its jurisdiction if the applicant has lodge a preliminary administrative appeal with the competent authority.

Thus, under Congolese law, it is accepted that the court hearing a challenge to the award decision is competent to pronounce, at the request of the ARMP, the final lapse of a contractor, supplier or public service provider who will be guilty of improbity ${ }^{13}$.

Moreover, since the public contract is a synallagmatic contract requiring reciprocity, the party who violates the contractual stipulations and thus prejudices the interests of the other may bring civil liability before the judicial court.

At this level, recourse to litigation for compensation for damage caused by contractual or tortious liability falls within the ordinary jurisdiction.

The doctrine admits in this connection that, for a fault committed during the award of a public contract, the criminal conviction may lead to civil compensation for the damage caused. The judicial judge is thus authorized to order the confiscation of the guarantees constituted by the company and its exclusion from the public order for a duration not exceeding five years. This sanction will be final in case of recidivism.

In addition, in criminal matters, the Decree establishing, organizing and operating the ARMP, for lack of uniform deadlines to initiate public action for each incrimination under the law on public procurement, retained a delay of fifteen (15) to seize, in case of absence of decision of the commission of dispute, the repressive judge. This period is increased by thirty (30) days following the lodging of the administrative appeal or the failure to reach a friendly settlement ${ }^{14}$.

However, in general, according to the article 153 of the congolese constitution a minister who commits a crime (like corruption or another crime related to public procurement) can be pursued and condamned by the Court of cassation in first and last degree but in respecting conditions fixed by the article 166 of the same constitution : The vote of the absoluted majority of the members of the National Assembly. But in the practice it is so hard when the Governement has also the parliamentary majority. This provision constitutes in fact a blockage to the implementation of the judicial control of the relevant ministries. To

13 According to article 81, paragraph 4 of the Congolese law on public procurement, constitutes the act of improbity, including the fact of being guilty of collusion with third parties for the purpose of making offers at artificial levels and non-competitive, to the detriment of the competent authority; overcharging and / or false invoicing; to try to influence the evaluation of the bids or the decisions of attribution, notably by proposing a payment more or less undue; be recognized, by a judgment which has become res judicata, liability for breach of contractual obligations in the performance of previous contracts, to engage in acts of corruption and fraudulent maneuvers.

14 Article 193 of Decree No. 10/22 of 2 June 2010 on Procedural Manual of the Law on Public Procurement. 
this must be added the corruption that characterizes the legislative power (during parliamentary control) and the judicial system in DR Congo. Therefore, since the entry into effect of the current congolese constitution in 2006 to now, seeing a minister to be pursued and condamned in DRC unfortunately remains utopian depite abandonment of public procurments projects and embezzlement of public funds destined for them.

Besides, let's observe that the congolese constitution (article 99) provides that the President of the Republic and the ministers have to declare their familial patrimony before the beginning of their functions and at the end of this before the constitutional court. But in the practice, again, the control concerns only the entrance and there is no transparency. That's why they become too powerfuls and opulents.

\section{CONCLUSION}

As demonstrated farther, infrastructure projects are very important for the Democratic Republic of Congo, particularly in view of its strategic location in central Africa, its dynamic demography and its innumerable natural resources. All of these assets can be beneficial for the Country only thanks to an effective and efficient control. There are many acts and institutions created for realizing this target. But their control is not efficiently implemented.

For example, the procurement and contract execution process may give rise to the political and / or criminal responsibility of a member of the government or the manager of a public company, a public institution or a public service.

According to the Congolese constitution in force, the policy of the Nation, as led by the government, is defined in consultation with the President of the Republic. The Government is responsible for the National Assembly through the oral or written question with or without debate, follow-up of the vote, the interpellation, the commission of inquiry, the question of topicality, the hearing, the hearing by the commissions ${ }^{15}$, the motion of no confidence or censure ${ }^{16}$.

However, in practice, excessive and unlawful search for benefits inevitably leads to violation of established rules and impunity. As a result, the law of public procurement tends to disappear more and more because of the persistence of the phenomenon of money laundering and other constraints.

\section{BIBLIOGRAPHY}

\section{Official documents}

Law No. 11/002 of 20 January 2011 revising certain articles of the Constitution of the Democratic Republic of Congo;

15 Article 152 of the Rules of Procedure of the National Assembly of 23 December 2003 in the Official Journal of the Democratic Republic of the Congo, special issue of 20 February 2007.

16 Art. 146 and 147 of the DR Congo Constitution. 
public Procurement In Infrastructure Projects

Law No. 10/10 of 27 April 2010 on public Procurement;

Decree No. 10/21 of 2 June 2010 on the creation, organization and functioning of the Public Procurement Regulatory Authority;

Decree No. 10/27 of 28 June 2010 on the establishment, organization and functioning of the General Directorate for the Control of Public Procurement;

Decree No. 10/32 of 28 December 2010 establishing, organizing and operating the Project Management and Public Procurement Unit;

Decree No. 10/22 of 2 June 2010 on the Procedural Manual of the Law on Public Procurement; Decree No 10/34 of 28 December 2010 laying down the procedures for the approval of public contracts and public service delegations;

Decree No 10/34 of 28 December 2010 setting the thresholds for the award, control and approval of public contracts;

Decree No. 039/2001 of 08 August 2001 establishing, organizing and operating the Central Coordination Office.

\section{Books}

ESAMBO KANGASHE, Le droit congolais des marchés publics (The congolese public procurement law),l'Harmattan DR Congo, Kinshasa, 2016, 282 pages

MWILANYA WILONDJA, Le droit congolais des marchés publics (The congolese public procurement law), l'Harmattan DR Congo, Kinshasa, 2016, 350 pages.

CGMP, Manuel de passation des marchés publics et procédures techniques (Public procurement manual and technical procedures), Kinshasa, 2014, 66 pages. 